\title{
What the Public Librarian Wishes the School Librarian Knew
}

\author{
JUDYT.MELSON AND JANET INGRAHAM DWYER
}

W hen it comes to serving children and teens, schools and public libraries share a mission-to support them and help them succeed. How we each carry this out differs widely, but when we work together, all our families and children have the support and encouragement they need to be successful both in school and in life.

Schools serve specific audiences (children from kindergarten through grade 12). Some school districts may also have prekindergarten classes that feed into their K-12 systems. Public libraries are tasked more broadly with serving everybody in their community, from babies to senior citizens.

In serving these distinct but overlapping audiences, schools and public libraries can collaborate and partner in many ways to support kids and families, from homework and reading support to providing value-added subscription research databases, programs, and even professional development.

Collaboration involves all levels of school districts and the public libraries, from administrators to classroom staff and librarians. Administrators engage with fellow administrators and commit to a level of interaction. School superintendents and public library directors lead the way by meeting and sharing their common interests.

A school superintendent who believes the local public library is a partner in education enables the school librarian to reach out during school hours and invite the public librarian into the school to share access to students. The public library director who believes the local school is a partner in education can smooth the way: removing barriers to the development of educator library cards with special borrowing privileges for teachers, establishing fine forgiveness strategies, and setting up other services to support students to enhance teachers' access to library resources.

When administrators partner to identify their common interests and appropriate strategies to meet these interests, librarians are empowered to work together without worrying about whether or not their districts or libraries are on board.

With this in mind, the AASL/ALSC/YALSA Interdivisional Committee on School-Public Library Cooperation offers this top ten list of items public librarians wish their school library counterparts knew about the nature of being a public librarian today. We hope this will lead to improved collaboration that impacts positive outcomes for kids and families.

1. We want to work with you. Let's meet and talk about how we can support each other. We know it's not our role to implement curriculum or directly meet learning standards, so collaborate and help us align our knowledge and resources to what your students need.

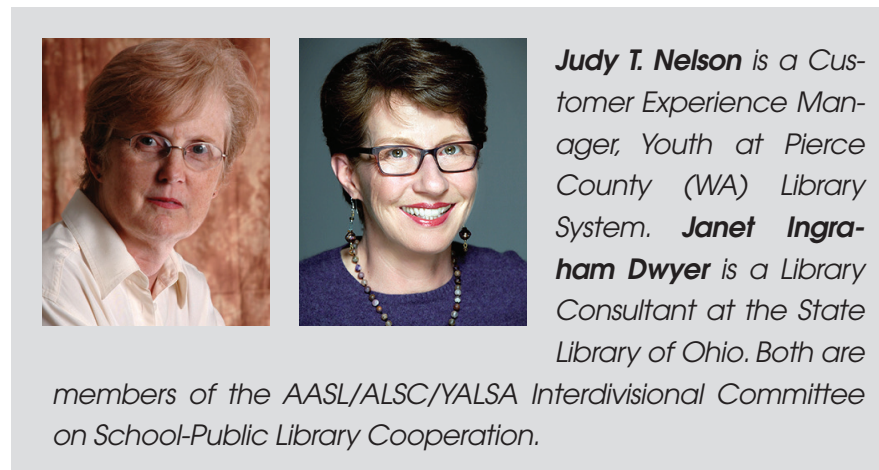


When we know what you and your students need, we can support you and your teachers as they assign work. We can share the types of resources we have access to, so you are better able to direct your students to not only the resources they use at school, but also valuable supplemental resources that support their assignments.

2. Our facilities are open after school hours. We're not competing with you! Instead, we're here to complement your work. Public libraries typically have later hours than school libraries, may be open evenings and on weekends, and are open all summer long.

3. Public libraries have free Wi-Fi and computers for students who may not have technology in their homes. Students can search the Web and use software to do their homework as well as practice using a mouse and keyboard to develop the skills they may need to take computerized standardized assessments.

4. Public librarians are educators but not certified teachers, and we do recognize the difference. We offer students support through homework help centers, assistance with their assignments, summer reading/learning programs that address the summer slide, after-school informal STEM programming, technology access and education, and more.

5. Public libraries are gold mines of informational and literary texts: books, magazines, DVDs, audiobooks, and electronic resources. Collection size and borrowing privileges may vary, but many of us have access to still more texts through system-wide catalogs, consortium arrangements, and interlibrary loan.

Because we serve everyone in our community, our collections have broader ranges than your school library is allowed to have. That means your students who may be reading either above or below grade level can find a wider selection of texts of interest at the public library.

Encourage your teachers to share assignment alerts to help us prepare for materials and topics your students will ask for. Public librarians can then plan services and make book selection decisions with better awareness of upcoming demand.

6. In this era of kindergarten readiness, public libraries are incubators for early literacy. Many children's librarians offer basic early literacy education for parents and caregivers, thanks to the PLA/ALSC's Every Child Ready to Read @ your library initiative and other early literacy resources and frameworks.

Early experiences in literacy-rich, supportive environments are a far better alternative than later intervention to address reading and learning deficits. The public library can be a literacy lifeline for families whose children are not enrolled in preschool and an important supplement for families whose children are in preschool.

7. Public librarians provide stepping stones to career readiness. We engage middle school and high school students through volunteer opportunities and leadership opportunities, such as teen advisory boards (TABs) that help plan library programs and advise on decoration and use of the teen space.

Public librarians may have access to subscription careerdevelopment resources. We may also partner with you on career exploration programming or provide volunteer opportunities to support the fulfillment of community service hours that many school districts require for graduation. We may have part-time jobs available for high school students to gain meaningful work experiences and earn cash.

8. We can share professional development opportunities. Perhaps we can submit joint grant applications? Let's consider providing reciprocal continuing education opportunities, hosting joint in-service days, or just setting a time to meet together with the public library's youth services staff and your school district's media center staff.

9. By working together, we can both expand our reach to parents and caregivers by disseminating information for one another. As community information centers, public libraries can distribute school information to the community at large, hold school board meetings in our meeting rooms, reach parents of incoming students (and even future parents), and connect with the business community, which may not be aware of what the school district is working on or currently providing.

The school library can directly communicate with parents of students to inform them of upcoming programs and services at their public libraries, especially regarding summer programs and services.

10. Public librarians can use lots of support and help from you to increase their awareness of day-to-day realities at your school, such as instructional practice, budget, aggregate test scores and other important data, and more. What can you share with us about at-risk populations, languages spoken, or any special situations with the kids in your school?

Help us understand your students' needs. Share school district data that can help with public library planning including graduation rates, reading scores, school enrollment trends, and so on. All this data will enable the public library to perform a needs assessment to discover gaps in their resources and supports for students, families, and educators.

Our communities will be better served if we talk and work together, and they expect us to cooperate. We can't wait to connect with you! \& 
6. Things can change without notice in schools. Research projects come and go depending on curricular changes and teacher staffing. If the books you bought in response to a previous school project don't get taken out this year, it could be because the teacher who gave out that assignment has retired or changed grade levels, or something similar.

7. School librarians are participants in the larger world of education reform. Common Core Learning Standards (CCLS)? Race to the Top? No Child Left Behind? Data Teams? The programs seem to change with the office holders at state and federal levels.

What isn't changing is that schools and educators are under the microscope to improve the quality of education. As educational partners with classroom teachers, school librarians are part of this reform and in many cases have to comply with state and federal teacher evaluation programs and standards. But as these reforms are often politically based, today's practices may be abandoned next year.

Lastly, the Common Core is good for libraries. Yes, it's hard to ignore the controversy and debate over the CCLS, nor should we. However, with its emphasis on student research, there is definitely a place at the table for librarians.

8. In smaller school districts, the librarian usually does her or his own collection development. Any resources or insights you have into new titles to add to the collection are welcome!

9. One of the most important things we can do is work on simple ways to become advocates for one another's programs. Both our worlds are marked by competition for resources and are always at risk for cutbacks. Together, we can flex our political muscles in a productive way.

10. We really believe in what you do and are continually impressed by the quality of the programming and services at public libraries! From summer reading, to helping families get library cards, to databases, the myriad offerings from public libraries are amazing, especially considering the limited budgets available. Thank you for all you do! ¿.

GETTING READY FOR PLAY!, continued from page 16

such as kitchen play items or puzzles, be prepared for sorting challenges when these materials mix together.

Remember also to create and maintain a digital space for your toy collection. Library websites can be particularly useful for offering information about how to use different types of toys for developing particular skills in early childhood. Programs can serve this purpose as well, so consider how best to connect programming with your toy collection. Whether you promote your circulating toys in your existing programs or create entirely new programs to highlight your toy collection, always focus on unstructured free play opportunities and parent-child engagement.

Finally, advocate for your toy collection and for the importance of providing access to toys and playtime for all children. As children's library professionals, "We need to communicate to parents, library staff, and community leaders the value of play in young children's lives." ${ }^{15}$ Public library toy collections are a fun and valuable way to support early literacy for every child. ¿.

\section{References}

1. Sue McCleaf Nespeca, “The Importance of Play, Particularly Constructive Play, in Public Library Programming," The Association for Library Service to Children, September 10, 2012, accessed August 8, 2015,
www.ala.org/alsc/sites/ala.org.alsc/files/content/Play_ formatted.pdf.

2. Kenneth R. Ginsburg, "The Importance of Play in Promoting Healthy Child Development and Maintaining Strong Parent-Child Bonds," Pediatrics 119, no. 1 (January 2007): 182.

3. Betsy Diamant-Cohen, et al., "We Play Here!: Bringing the Power of Play into Children's Libraries," Children and Libraries 10, no. 1 (Spring 2012): 3.

4. Ibid, 4.

5. Ibid, 3.

6. Sarah D. Sparks, "Key to Vocabulary Gap Is Quality of Conversation, Not Dearth of Words," Education Week, April 21, 2015, accessed Aug. 8, 2015, www.edweek.org/ew/ articles/2015/04/22/key-to-vocabulary-gap-is-quality -of.html.

7. Diamant-Cohen et al., "We Play Here!," 5.

8. “Toy Lending Library,” Lekotek, accessed April 23, 2015, www.lekotek.org/family-services/toy-lending-library.

9. Diamant-Cohen et al., "We Play Here!," 5.

10. McCleaf Nespeca, “The Importance of Play," 9.

11. Ibid, 2 .

12. Ibid, 6 .

13. Diamant-Cohen et al., "We Play Here!," 8.

14. Ibid, 10.

15. McCleaf Nespeca, “The Importance of Play,” 10. 